\title{
The Psychometric Properties of School Belonging Scale for Middle School Students
}

\author{
Bekir Direkci ${ }^{(\mathbb{D}) \text {,*, Mehmet Canbulat }}{ }^{(\mathbb{D})}$, Ibrahim Hakki Tezci ${ }^{(D)}$, Serdar Akbulut ${ }^{(\mathbb{D} 1}$
}

${ }^{1}$ Akdeniz University, Education Faculty, Antalya / Turkey

\author{
ARTICLE HISTORY \\ Received: Nov 042019 \\ Revised: Mar 032020 \\ Accepted: Apr 152020 \\ KEYWORDS \\ Scale development, \\ School belonging, \\ Middle school students, \\ Factor analysis,
}

\begin{abstract}
This study aimed at developing a valid and reliable scale to determine middle school students' sense of school belonging. In this respect, the relevant literature on the concept of belonging was reviewed, interviews were conducted with field experts and middle school students to determine items to be included in the scale. An item pool was created based on the findings of these processes. Later, a pilot form was prepared by taking the opinions of 2 field and 2 measurement and evaluation experts so as to ensure that the scale items represent the structure measured. This form was administered to 287 middle school students studying in the 2018-2019 academic year, and the final scale obtained as a result of exploratory factor analysis was applied to 568 middle school students in a different school. For validity evidence, exploratory factor analysis (EFA), confirmatory factor analysis (CFA) and hypothesis test findings; for reliability, findings of Cronbach Alpha and composite reliability coefficients were used. According to the exploratory factor analysis, the scale consisted of 4 factors with 23 items, and the total variance explained was $63.88 \%$. As a result of the secondorder confirmatory factor analysis of the obtained structure, the fit indices of the unidimensional model showed that the model was verified. The internal consistency coefficient of the developed model was $\alpha=.92$ and the composite reliability coefficient was .97 . These findings showed that the scale had psychometric properties that could be used in future research.
\end{abstract}

\section{INTRODUCTION}

The education system, one of the most significant indicators of the countries' development levels, comprises a systematic process. Many sub-elements such as students, teachers, parents, school administrations, course materials, school infrastructure and so on are administered properly and regularly by the Ministry of National Education and its affiliated institutions so that children as the future of the countries can involve in a contemporary educational process. Although there are partial differences between the educational timetables across countries, this process continues in a similar manner in each country. As in many other industrialized countries, children start school to carry out educational activities from an early age and spend at least 30 weeks of a year in formal education institutions starting from early childhood in 
Turkey. During the 12-year compulsory education process designed as $4+4+4$, children attending school receive training in many different disciplines according to their age and developmental characteristics. For the Turkish context, this process is carried out in two different ways as normal (full-day) and half-day (dual) education and it is planned to start normal (full-day) education in all schools by the end of 2019. The full-day education is applied in all OECD countries, with an average of 7-8 hours of schooling. However, children in Turkey attend additional support and training courses at school right after their compulsory courses are over. Therefore, the time spent by some children with schoolmates and teachers on an ordinary school day may even exceed that of their parents (Cemalcilar, 2010). When we consider the length of duration taken into consideration, we may state that it is important for children to feel happy during their time in school and to see school as a second home for their social, academic and cognitive development. The fact that the children love the school, feel the sense of belonging and have a positive attitude towards it have a positive effect on achieving the anticipated objectives of the curriculum and increasing academic success. Now that the students' sense of school belonging is boosted, the potential negative perspectives and attitudes towards the school are thought to disappear since the concept of belonging is a multidimensional structure that we encounter in every aspect of our lives with a different form. It is sometimes attributed to an institution such as a family and school, an individual or a community, and an area or place within the scope of the need for a common structure or origin such as religious or ethnic identity (Sar1, 2013). Since school is naturally perceived as a form of society, it is important to discuss and examine the concepts of society within the school. Just as an individual's sense of belonging to social groups and society brings out the feeling of protecting and improving this structure, it is very important for a student to feel himself as a part of the school so as to protect and promote it (Akar Vural, Özelçi, Çengel, \& Gömleksiz, 2013). Therefore, the concept of belonging, which is a sociological and psychological term and has an important place in Maslow's hierarchy of needs, is a critical not only for the society but also for the school to achieve curriculum objectives. In this study, researchers discussed the concept of belonging within the context of student-school relationship. When the relevant literature is examined, it is seen that different researchers investigated and presented findings related to its various aspects. Considering the large time period spent by students in the school, the studies were conducted to measure or increase the sense of school belonging. These studies mainly revealed the positive effects of belonging on various psychological, social and academic outputs (Ireson \& Hallam, 2005; Osborne \& Walker, 2006; Roeser, Midgley \& Urdan, 1996). In general, students with higher sense of school belonging were found to be less anxious and isolated, more autonomous and prosocial, more successful and more intrinsically motivated in classes (Cemalcilar, 2010; Finn, 1989; Goodenow \& Grady, 1993; Sar1, 2013; Van Ryzin, Gravely \& Roseth, 2009; Voelkl, 1997). In addition, it was revealed that these students placed more emphasis on education, participated in-and-out-of-class activities more, had higher selfesteem and higher attendance rates and better relations with teachers and peers, and they were more satisfied with their current situation (Cemalcilar, 2010). On the other hand, lack of sense of belonging was associated with feelings of alienation and loneliness, low academic achievement, negative attitudes towards school, behavioural problems, low school attendance rate, social rejection, isolation and dropout (Edwards \& Mullis, 2001; Voelk1, 1997). Moreover, the lack of sense of school belonging was reported to be a strong predictor of loneliness (Hagerty, Williams, Coyne \& Early, 1996; Pretty, Andrewes \& Collett, 1994).

Especially in the international literature, the importance of the school belonging for students, its development and relationship with other outcomes of education have been the subject of many studies. As noted above, the most prominent finding in these studies was the effect of school belonging on students' academic achievement. The researchers such as Booker (2006); Cemalcilar (2010); Finn (1989); Goodenow (1992) and Osterman (2000) revealed that the sense 
of school belonging was positively correlated with high achievement, academic motivation and academic self-efficacy, and showed a high negative relationship with drop-out rate.

Anderman (2002); Hagborg (1994); Isakson and Jarvis (1999) also reached similar findings. They characterised the sense of high school belonging to high academic achievement and supported the positive relationship between school belonging and academic achievement. Bond et al. (2007), who carried out studies with middle school students, found that students' school belonging level promoted their academic achievement and the rate of continuing to further educational stages. Adelabu (2007) and Israelashvili (1997) associated students' school belonging level with their future expectations. In their studies, they revealed that there was a positive relationship between students' sense of school belonging and their future expectations. In other words, they enounced that the students with a high level of school belonging had a more positive perspective towards the future.

Pehlivan (2006), who examined the reasons for the absenteeism of middle school students, specified the reasons as boredom at school, disliking school and lessons, lack of friends' encouragement and expectations about education. He suggested that these reasons were closely related to the sense of school belonging. Booker (2006) stated that school belonging was an important part of a whole because it affected students' school attendance, academic achievement and educational outcomes related to psychological well-being. Goodenow (1992) stated that the inadequacy or low level of school belonging would have to be considered as a decrease in participation in school and lessons and as a result of this, it would be possible to face with low academic achievement and even drop out.

The OECD report (Willms, 2003) of the PISA study, published in 2000 and conducted in 43 countries to examine the 15-year-old student group, states that there is a direct link between the sense of school belonging and students' participation in school activities. In this report, another factor related to school belonging is expressed as "dropping out". As it is underlined in the report, it is suggested that the students who do not develop a sense of school belonging try to create a different channel for belonging necessity, which leads to the emergence of antisocial behaviour models or the outbreak of violence-prone student groups such as school gangs.

As stated in the relevant literature, the sense of school belonging plays a crucial role in educational life of the students. For this reason, several scale development studies were carried out to determine the level of students' sense of school belonging. In the literature, the first study we come across is the study of Goodenow (1993) who developed the Psychological Sense of School Membership (PSSM) Scale through the data of 755 students studying in middle ( $\mathrm{N}=454)$ and high $(\mathrm{N}=301)$ schools. As a result of analyses, a final 18-item scale having .80 internal consistency value. The scale items consisted of the statements which measured subjective and individual perspectives of the students towards the school rather than an objective evaluation. This scale is one of the most frequently used data gathering instruments regarding the school belonging. It was used by many researchers such as Isakson and Jarvis (1999), Mcmahon et al. (2008) and Sar1 (2013) in the relevant field. Based on the findings of Goodenow (1993), the scale had the required psychometric features both in English and Spanish versions. The relevant scale was adapted by Alkan (2015) who confirmed the construct validity and the efficiency of internal consistency.

Like Goodenow (1993), Aslan and Duru (2017) developed a scale to measure students' sense of school belonging, as well. They collected their data from middle school and high school students in order to obtain a practical scale that can be used in the studies carried out both school levels. In the end of the study, they developed a 10-item scale consisting of two sub factors, satisfaction and loneliness. The scale acquired the required psychometric features both in EFA and CFA, and it was brought into use of the researchers. 
Malone, Pillow and Osman (2012), on the other hand, focused on general belongingness and developed a scale to measure this phenomenon. The data were collected through online computer-administered surveys and the analyses of EFA and CFA attested the usability of a 12item scale consisting of two sub-factors, acceptance/Inclusion and lack of rejection/exclusion. The psychometric properties of this scale were also examined by Duru (2015) who confirmed the two-factor structure and highlighted that the scale can used to measure general belongingness levels of the university students.

When the literature related to the concept of school belonging is examined, it is observed that this concept is of great importance both in students' current educational life and in shaping the future road map. Measuring the students' school belonging with a valid and reliable measurement tool, identifying the ones having low levels of belonging and carrying out studies to increase their belonging to school will make an important contribution on behalf of countries. The school belonging scale, which is intended to be developed within the scope of this research, aims to fill this gap in the literature and to provide a valid and reliable measurement tool for future research. The scales presented above either focused on the concept of general belonging or were developed by collecting data from middle-school and high school students. This scale is, on the other hand, merely focused the concept of school belonging and collected the data from middle school students. Therefore, it is thought that it will reflect the school belonging levels of the middle school students more precisely.

\section{METHOD}

\subsection{Study Group}

The study group consisted of 855 middle school students who were divided into three groups. The first form of the scale was administered to the Group I. After analysing and performing exploratory factor analysis, the final form was administered to Group II. The data obtained from this application were used in second-order confirmatory factor analysis. Later, the scale was applied to Group III to compute the hypothesis test. Descriptive statistics on research groups are presented in Table 1.

Table 1. Descriptive statistics for research groups

\begin{tabular}{|c|c|c|c|c|c|c|}
\hline Total Data & Raw Data & Analysis Data & & & $n$ & $\%$ \\
\hline \multirow{18}{*}{855} & \multirow{6}{*}{287} & \multirow{6}{*}{$\begin{array}{c}218 \\
\text { (Group I) }\end{array}$} & \multirow[t]{2}{*}{ Gender } & Female & 113 & 51.83 \\
\hline & & & & Male & 105 & 48.17 \\
\hline & & & \multirow[t]{4}{*}{ Class } & 5 & 47 & 21.5 \\
\hline & & & & 6 & 40 & 18.3 \\
\hline & & & & 7 & 76 & 34.8 \\
\hline & & & & 8 & 55 & 25.4 \\
\hline & \multirow{6}{*}{312} & \multirow{6}{*}{$\begin{array}{c}276 \\
\text { (Group II) }\end{array}$} & \multirow[t]{2}{*}{ Gender } & Female & 139 & 50.36 \\
\hline & & & & Male & 137 & 49.64 \\
\hline & & & \multirow[t]{4}{*}{ Class } & 5 & 61 & 22.10 \\
\hline & & & & 6 & 74 & 27.89 \\
\hline & & & & 7 & 86 & 31.88 \\
\hline & & & & 8 & 55 & 19.92 \\
\hline & \multirow{6}{*}{256} & \multirow{6}{*}{$\begin{array}{c}212 \\
\text { (Group III) }\end{array}$} & \multirow[t]{2}{*}{ Gender } & Female & 113 & 53.30 \\
\hline & & & & Male & 99 & 46.70 \\
\hline & & & \multirow[t]{4}{*}{ Class } & 5 & 42 & 19.80 \\
\hline & & & & 6 & 33 & 15.60 \\
\hline & & & & 7 & 78 & 36.80 \\
\hline & & & & 8 & 59 & 27.80 \\
\hline
\end{tabular}


The groups were determined according to some principles. First of all, it was decided to carry out the study in schools located in Antalya province in order to provide ease of access to data and economic principle. All the data obtained were collected from public schools. Secondly, it was aimed at increasing the generalizability of the study to the middle school students by including the students from all middle school stages. Therefore, EFA and CFA analyses were performed with the data collected from different groups considering the criteria that EFA and CFA cannot be performed with the same groups (Fabrigar, Wegener, Strahan, \& MacCallum, 1999). Another validity method was hypothesis testing. The analysis and study groups included in the research are summarized in Table 2.

Table 2. Study groups and statistical analyses performed in the research

\begin{tabular}{lll}
\hline Study Group & Statistical Analysis & Evidence \\
\hline Group I & Exploratory Factor Analysis (EFA) & Construct Validity \\
\hline Group II & Confirmatory Factor Analysis (CFA) & Construct Validity \\
\hline Group I+II & Item Analysis, Cronbach Alpha, & Reliability and Item \\
& Composite Reliability & Discrimination \\
\hline Group III & Hypothesis Test $(t$-test) & Construct Validity \\
\hline
\end{tabular}

\subsection{Procedure}

While forming the items to be included in the school belonging, the literature on the concept of belonging was reviewed and basic knowledge and theories related to this concept were analysed. However, due to the lack of the number of studies merely focusing the concept of school belonging in this field, an item pool was formed only after in-depth interviews were conducted with field experts and focus group interviews were made with middle school students. During the construction of the item pool, it was asked to 2 field and 2 measurement and evaluation experts to reflect the construct to be measured. The field experts were the academicians who worked the concept of belonging and carried out scale development studies.

A five-point Likert-type rating was used for the statements in the scale: Strongly Disagree (1), Disagree (2), Partly Agree (3), Agree (4), and Strongly Agree (5). After the feedback received from expert opinions, necessary changes and arrangements were made in the scale items. The items having clarity and understandability problems were corrected and those of which both experts had a consensus on removing were eliminated. In the last stage, two language experts checked the scale to ensure the suitability of the scale in terms of language. The items in the scale were reviewed and arranged in line with the opinions and ideas of the experts regarding the use of punctuation marks and spelling. The scale was applied to the pre-trial group of 15 students before being applied to the study groups. During the implementation, students' reactions were monitored and it was concluded that the instructions and items prepared for the scale were clearly understood. The data obtained from the preliminary application were not included in the data of the main research groups.

\subsection{Data Analysis}

Several analyses were performed to reveal the psychometric properties of the measurements after administering the 37-item pilot form to three research groups. First, exploratory factor analysis (EFA) was computed to obtain evidence about the construct of the measurements. Before applying the EFA, it is necessary to examine whether data meet the assumptions of the factor analysis. The sample size is the first step of this analysis (İlhan \& Çetin, 2014) There are different views concerning the number of participants that should be included in factor analysis studies. Cattell (1978) suggests that the number of people in the study group should be 3 to 6 
times greater than the number of items in the scale for factor analysis and 200 participants are acceptable for factor analysis and 500 individuals are considered as an optimum number. Hair, Anderson and Grablowsky (1979) stated that the number of the study group should be 20 times as many as the number of scale items in the factor analysis. Comrey and Lee (1992) defined the criteria for factor analysis for the number of participants as 100 inadequate, 200 as average, 300 as good, 500 as satisfactory and 1000 as excellent. Ferguson and Cox (1993) stated that 100 participants should be the minimum for the factor analysis. Kline (1994), on the other hand, stated that the number of data could be reduced up to 100 in cases where the number of factors is low and significant, but a sample of 200 people is required for the reliability of the results in more complex structures. When considering various opinions in determining the number of sample for factor analysis, it is seen that there are different criteria. In this respect, it is suggested that each researcher should be able to meet at least two of the mentioned criteria in accordance with the characteristics of the research (Çokluk, Şekercioğlu \& Büyüköztürk, 2012). In this study, it can be said that the data of 218 people in the first group is sufficient for factor analysis since it meets multiple criteria stated above. Kaiser-Meyer-Olkin (KMO) Test for Sampling Adequacy and the Bartlett test where normality is tested are other statistical ways to test the assumptions of the factor analysis. Factor analysis can be performed when the KMO value is higher than .60, which is an indication of sufficient sample size, and when the Bartlett test is statistically significant, which indicates that multivariate normality is achieved (Büyüköztürk, 2016).

EFA encompasses various techniques such as maximum likelihood factor analysis, principal component factor analysis and unweighted least-squares analysis. (Tabachnick \& Fidell, 2007). Stevens (1996) stated that compared to other techniques, principal component analysis is a factorization technique that should be preferred primarily because it is psychometrically more powerful and mathematically easier to perform, and has more positive effects in dealing with factor uncertainty problems. Due to its features, the principal component analysis was found suitable for use as a factorization technique in this study. It is suggested that oblique rotation methods should be preferred in case of inter-factor relationship (Tabachnich \& Fidel, 2007). Since the factors in the relevant model are related ( $r>30)$, Promax rotation method, one of the oblique rotation methods, was used. When interpreting the results obtained from EFA, the factor loading of .50 was taken as the cut-off point because it was considered as satisfactory to include an item in the theoretically predicted factor (Awang, 2015). Items below this value were removed from the scale. When interpreting the findings obtained from EFA; the common variance values $\left(\mathrm{h}^{2}\right)$ shown in all the factors were also taken into consideration (İlhan \& Çetin, 2014). It was stated that if the item $h^{2}$ value, the expression of the sum of the squares of the factor loadings that an item showed in all factors, is low, the item should be removed from the scale in the factor analysis (Kalayc1, 2010). In general, when the studies in the literature are examined, it is recommended that the .50 value for the common variance should be taken as a criterion (Thompson, 2004). However, it is often not possible to obtain high common variance values because the field of study is in the social sciences and human behaviour represents various latent structures. Costello and Osborne (2005) stated that taking the .40 value as a criterion for the common variance would be more meaningful and accurate for the social sciences. Tabachnick and Fidell (2007) stated that if a common variance of an item is lower than .20 , it indicates that the items measure different situations. When this view is taken into consideration, the criterion for the common factor variance should be taken as .20 at least (Şencan, 2005).

Confirmatory Factor Analysis was used to obtain information about the accuracy of EFA results and to test the data-fit measurement model which was formed as a result of a theoretical basis. If $\chi^{2}$ value obtained from the CFA findings of the model is significant, it is considered as evidence that the model is not confirmed by the collected data. However, it is important to note 
that; The value of $\chi^{2}$ is sensitive to the increase in the number of sampling and tends to be significant as the number of data in the study increases. In this case, $\chi^{2}$ value which is not meaningful in practice might be significant in the analysis results due to the sample size (Byrne, 2010; Kline, 2011). For this reason, it is necessary to examine the standardized value obtained by dividing $\chi^{2}$ to the degree of freedom and the other fit indexes in the literature when deciding whether the model is validated in the study (Hu \& Bentler, 1999). Several fit indices are used to demonstrate the adequacy of the model tested in the CFA. In this study, the following indices were examined for CFA: chi-square goodness of fit test, goodness of fit index (GFI), adjusted goodness of fit (AGFI), normed fit index (NFI), non-normed fit index (NNFI), incremental fit index (IFI), comparative fit index (CFI), root mean square error of approximation (RMSEA), standardized root mean square residual (SRMR), parsimony normed fit index (PNFI) and parsimony goodness of fit index (PGFI).

Hypothesis testing was applied to provide different validity evidence for the study. According to the literature (Cemalcilar, 2010; Edwards \& Mullis, 2001; Voelkl, 1997), it is expected that students with high school attendance will have higher school belonging and students with low school attendance will have low scale scores on the scale. On this basis, it is expected that there will be a difference in school belonging scores in low and high absenteeism groups. For this purpose, the individuals of the third research group were divided into two different groups (low and high absenteeism) and the school belonging level was compared by t-test.

The reliability of the scores obtained from the school belonging scale was calculated by using composite reliability and Cronbach Alpha methods. In order to determine the level of discrimination of the items in the scale, 27\% upper-lower group comparisons and item-total correlation were checked. Statistical package programs were used to compute Cronbach Alpha reliability and item analysis.

\section{FINDINGS}

\subsection{Construct validity}

EFA, CFA and hypothesis testing were used to test the construct validity of the items in the scale.

\subsubsection{Exploratory Factor Analysis (EFA)}

$\mathrm{KMO}$ value calculated for the adequacy of the sample size was found to be .916 . Besides, the Bartlett test, which was computed to check the multivariate normality assumption, was significant $\left(\chi^{2}=3103.889, d f=253\right)$. According to these results, it can be concluded that the data are suitable for factor analysis. As a result of the principal components factor analysis and varimax vertical rotation method in EFA, the four-factor structure explaining $63.88 \%$ of the total variance was found to be appropriate for the theoretical basis. The scree plot obtained for determining the number of factors is shown in Figure 1.

The scree plot is a suggested auxiliary graph for determining the number of factors. Compared to determining the factors through eigenvalue, this graph generally provides a more clear-cut picture of the factors and makes it easier to read the structure graphically. When interpreting the obtained graph, the point at which linearity starts is taken as a cut-off point in determining the number of factors. As seen in the graph, the line gains linearity after 4 bars which is interpreted as an indication of the 4-factor structure in the data set.

According to the findings obtained from the EFA, 5 items were removed since their factor loadings were below the acceptable level. 9 items were excluded from the scale since they showed high factor loadings in more than one sub-factor. Accordingly, all of the items on the scale had a factor loading above the pre-determined cut-off point (.50). In addition, it was found that the common factor variances of all items in the scale were .30 and above and met the 
required criteria. When the items in the factors and the theoretical basis were taken into consideration, the first factor was named as School Engagement (SE), the second factor was Teacher Support (TS), the third factor was Friend Support (FS) and the fourth factor was Alienation to School (AS). Descriptive statistics related to the factors are presented in Table 3.

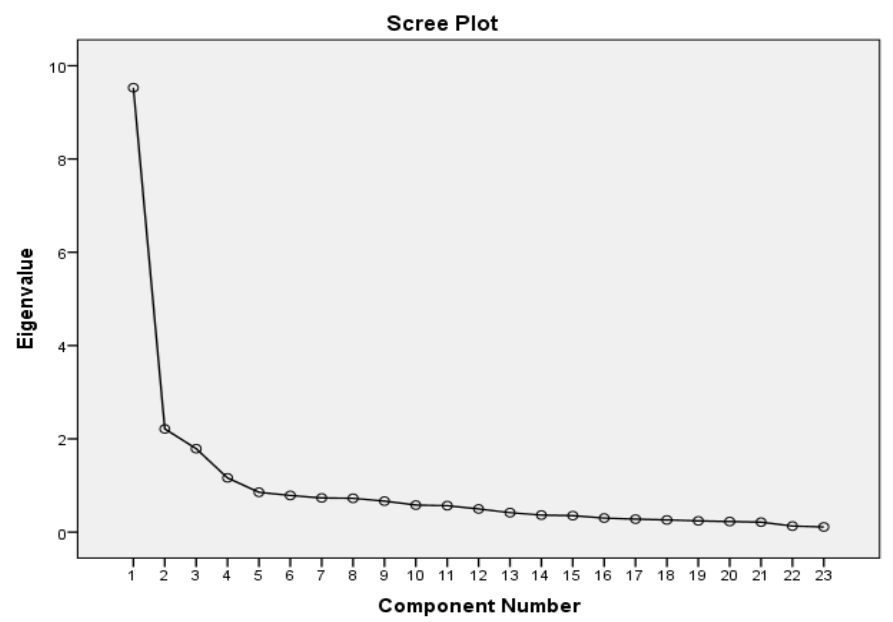

Figure 1. Scree Plot of School Belonging Scale

Table 3. School Belonging Scale Factor Structure and Factor Loadings

\begin{tabular}{|c|c|c|c|c|c|c|}
\hline \multirow{2}{*}{ Factor } & \multirow{2}{*}{ Item } & \multicolumn{4}{|c|}{ Factor Loadings } & \multirow{2}{*}{ Communalities } \\
\hline & & Factor 1 & Factor 2 & Factor 3 & Factor 4 & \\
\hline \multirow{10}{*}{ School Engagement } & M1 & .75 & .08 & -.03 & .04 & .57 \\
\hline & M6 & .82 & -.08 & .06 & .00 & .68 \\
\hline & M7 & .87 & -.03 & -.09 & -.16 & .79 \\
\hline & M8 & .60 & .02 & .08 & .10 & .38 \\
\hline & M11 & .53 & .09 & .01 & .21 & .33 \\
\hline & M12 & .74 & .04 & .01 & .06 & .56 \\
\hline & M21 & .85 & .10 & -.11 & -.09 & .75 \\
\hline & M24 & .88 & -.11 & -.01 & -.17 & .82 \\
\hline & M26 & .68 & .02 & .16 & .10 & .49 \\
\hline & M28 & .50 & .12 & .13 & .12 & .30 \\
\hline \multicolumn{7}{|c|}{ Variance Explained $41.43 \%$} \\
\hline \multirow{6}{*}{ Teacher Support } & M17 & -.06 & .87 & .14 & -.10 & .78 \\
\hline & M31 & -.10 & .91 & .06 & -.01 & .85 \\
\hline & M33 & -.04 & .97 & -.05 & .03 & .94 \\
\hline & M34 & .14 & .64 & -.03 & .05 & .43 \\
\hline & M35 & .02 & .93 & -.03 & -.03 & .87 \\
\hline & M37 & .15 & .84 & -.13 & -.01 & .75 \\
\hline \multicolumn{7}{|c|}{ Variance Explained $9.62 \%$} \\
\hline \multirow{4}{*}{ Friend Support } & M4 & .02 & -.02 & .74 & -.10 & .56 \\
\hline & M25 & -.12 & .01 & .75 & .17 & .61 \\
\hline & M29 & .16 & .07 & .68 & -.09 & .50 \\
\hline & M32 & .02 & -.05 & .78 & -.05 & .61 \\
\hline \multicolumn{7}{|c|}{ Variance Explained $7.78 \%$} \\
\hline \multirow{3}{*}{ Alienation to School } & M10 & .16 & -.10 & -.06 & .79 & .66 \\
\hline & M19 & -.12 & -.01 & -.04 & .74 & .57 \\
\hline & M20 & -.10 & .05 & .03 & .82 & .69 \\
\hline \multicolumn{7}{|c|}{ Variance Explained $5.06 \%$} \\
\hline & & TOTAL VA & $\begin{array}{l}I A N C E E X \\
63.89 \%\end{array}$ & LAINED & & \\
\hline
\end{tabular}




\subsubsection{Confirmatory Factor Analysis (CFA)}

The second-order CFA was applied to test whether the data of the second study group confirm that the structure consisting of 23 items and four factors obtained as a result of EFA is basically a model measuring a single dimension. This analysis provides evidence of whether the structure is unidimensional. The fact that the first structure composed of the items that are compatible with their own sub-factors has sufficient fit indexes is a prerequisite for performing secondorder CFA. In the first stage of the study, the second-order CFA was applied as a result of the agreement between the absolute and acceptable level of the CFA goodness of fit indices from the first stream. The fit indices related to the unidimensional model obtained are as follows; $\chi^{2} / \mathrm{df}=2.18, \mathrm{GFI}=.91, \mathrm{AGFI}=.85, \mathrm{CFI}=.97, \mathrm{NFI}=.95, \mathrm{NNFI}=97, \mathrm{IFI}=.97, \mathrm{RMSEA}=.065$, $\mathrm{SRMR}=.061, \mathrm{PNFI}=.85$ ve $\mathrm{PGFI}=.71$. In order to reveal the model-data relationship of the structure, the absolute and acceptable values of the fit indices and the fit index values obtained are shown in Table 4. As can be seen in the table, the fitness level of the unidimensional model obtained from the CFA is sufficient and that the model is validated. The obtained model is presented in Figure 2 below.

Table 4. Fit Index Values Obtained in CFA

\begin{tabular}{lllll}
\hline $\begin{array}{l}\text { Fit Indices } \\
\text { Examined }\end{array}$ & $\begin{array}{l}\text { Criteria for Absolute } \\
\text { Fit }\end{array}$ & $\begin{array}{l}\text { Criteria for } \\
\text { Acceptable fit }\end{array}$ & $\begin{array}{l}\text { Fit Indices } \\
\text { Obtained }\end{array}$ & Result \\
\hline$\chi 2 / \mathrm{df}^{*}$ & $0 \leq \chi 2 / \mathrm{df} \leq 2,5$ & $2,5 \leq \chi 2 / \mathrm{df} \leq 5$ & 2.18 & Acceptable fit \\
GFI $^{* *}$ & $.95 \leq \mathrm{GFI} \leq 1.00$ & $.90 \leq \mathrm{GFI} \leq 95$ & .91 & Acceptable fit \\
RMSEA $^{* * *}$ & $.00 \leq \mathrm{RMSEA} \leq .05$ & $.05 \leq \mathrm{RMSEA} \leq .08$ & .065 & Acceptable fit \\
AGFI $^{* * * * *}$ & $.90 \leq \mathrm{AGFI} \leq 1.00$ & $.85 \leq \mathrm{AGFI} \leq .90$ & .85 & Acceptable fit \\
IFI $^{* *}$ & $.95 \leq \mathrm{IFI} \leq 1.00$ & $.90 \leq \mathrm{IFI} \leq .95$ & .97 & Absolute fit \\
NFI $^{* *}$ & $.95 \leq \mathrm{NFI} \leq 1.00$ & $.90 \leq \mathrm{NFI} \leq .95$ & .95 & Absolute fit \\
NNFI $^{* *}$ & $.95 \leq \mathrm{NNFI} \leq 1.00$ & $.90 \leq \mathrm{NNFI} \leq .95$ & .97 & Absolute fit \\
SRMR $^{*}$ & $.00 \leq \mathrm{SRMR} \leq .05$ & $.05 \leq \mathrm{SRMR} \leq .10$ & .061 & Acceptable fit \\
CFI $^{* *}$ & $.95 \leq \mathrm{CFI} \leq 1.00$ & $.90 \leq \mathrm{CFI} \leq .95$ & .97 & Absolute fit \\
PNFI $^{* * * *}$ & $.95 \leq \mathrm{PNFI} \leq 1.00$ & $.50 \leq \mathrm{PNFI} \leq .95$ & .85 & Acceptable fit \\
PGFI $^{* * * *}$ & $.95 \leq \mathrm{PGFI} \leq 1.00$ & $.50 \leq \mathrm{PGFI} \leq .95$ & .71 & Acceptable fit \\
\hline
\end{tabular}

*(Kline, 2011) **(Bentler, 1980; Marsh, Hau, Artelt, Baumert \& Peschar, 2006) ***(Byrne \& Campbell, 1999) ****(Meydan \& Şeşen, 2011)*****(Schermelleh-Engel \& Moosbrugger, 2003)

Table 5 shows t-values for the unidimensional model obtained from the second-order CFA. As can be seen in the table, the t-test values were found to be between 10.38 and 13.44 for SE factor, between 10.37 and 14.24 for TS factor, between 5.72 and 6.91 for FS factor, and between 6.03 and 6.20 for AS factor. T value which is greater than 1.96 is an indication of significance at .05 level; but if it is higher than 2.56, it indicates that it is significant at .01 level (Jöreskog \& Sörbom, 2000; Kline, 2011). Accordingly, all the t values obtained in the CFA were found to be significant at .01 level. Finally, the t-values obtained from the CFA indicated that the number of the data was sufficient for factor analysis and the model-data fit was validated, so there were no items to be removed from the model. 


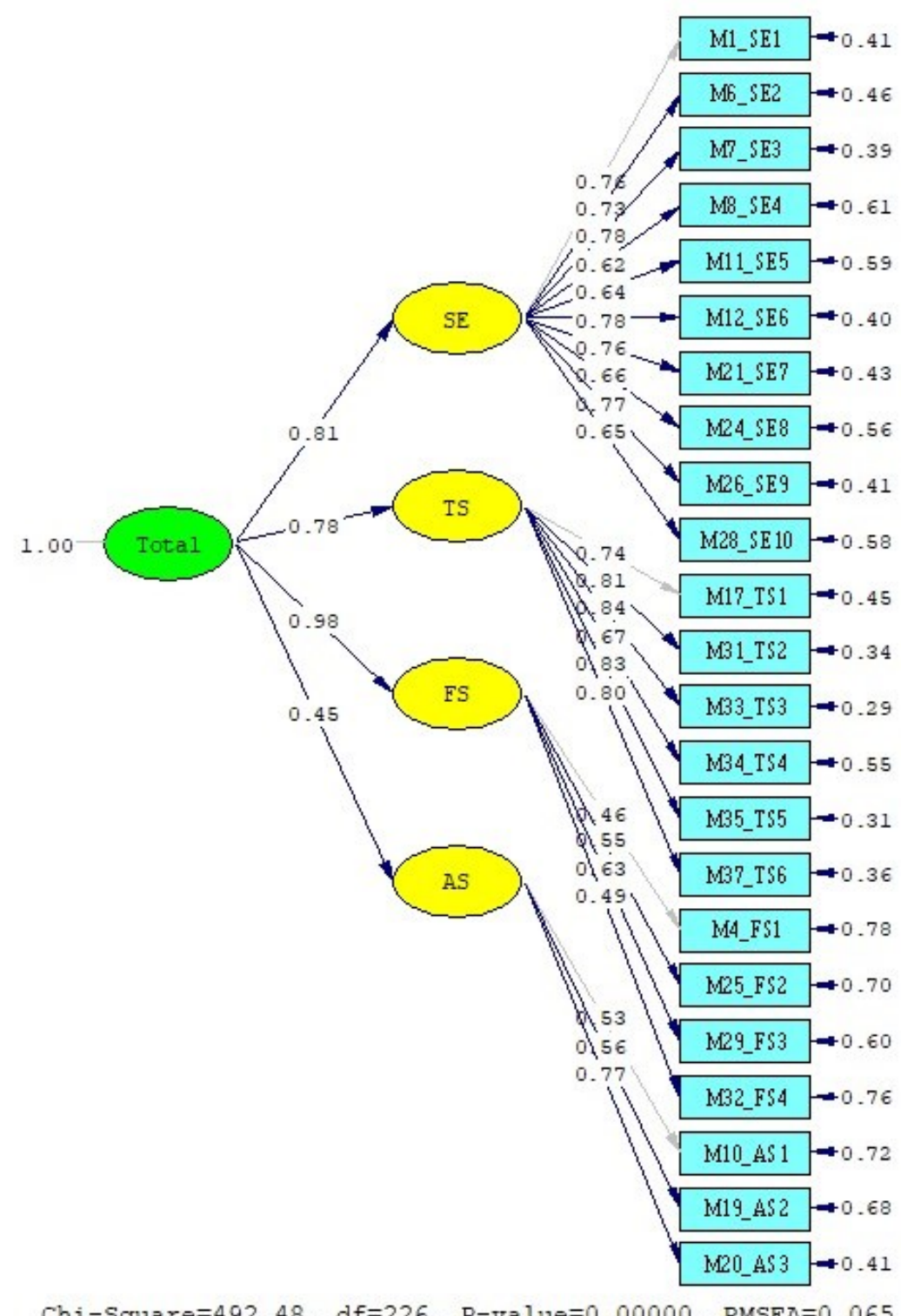

Chi-Square $=492.48, d f=226, P$-value $=0.00000$, RMSEA $=0.065$

Figure 2. Path Diagram regarding the model

Table 5. t-test Values obtained from CFA for School Belonging Scale for Middle School Students

\begin{tabular}{llllll}
\hline Item & $t$ value & Item & $t$ value & Item & $t$ value \\
\hline M1 & $13.00^{*}$ & M26 & $10.90^{*}$ & M4 & $5.72^{*}$ \\
M6 & $11.14^{*}$ & M28 & $10.75^{*}$ & M25 & $6.08^{*}$ \\
M7 & $12.60^{*}$ & M17 & $14.24^{*}$ & M29 & $6.91^{*}$ \\
M8 & $13.44^{*}$ & M31 & $14.00^{*}$ & M32 & $6.51^{*}$ \\
M11 & $10.38^{*}$ & M33 & $13.65^{*}$ & M10 & $6.03^{*}$ \\
M12 & $13.25^{*}$ & M34 & $13.36^{*}$ & M19 & $6.20^{*}$ \\
M21 & $13.23^{*}$ & M35 & $10.37^{*}$ & M20 & $6.11^{*}$ \\
M24 & $10.67^{*}$ & M37 & $11.11^{*}$ & & \\
\hline
\end{tabular}

* significant at the .01 level. 


\subsubsection{Hypothesis Test}

When the studies conducted in the literature are examined, there is evidence that the absentee rate is related to the feelings of school belonging. It is expected that students with less absentee rate will have more school belonging than students with more absentee rate. A hypothesis test is an analysis to perform whether the scale reflects such a situation in the literature. In the hypothesis test, the group was divided into two groups as low and high absentee rate. The $t$-test results of the scale scores according to absentee rate are shown in Table 6. The null and alternative hypotheses mentioned in the research are as follows:

$\mathrm{H}_{0}=$ School belonging scale scores of the students do not differ significantly according to the absentee rate.

$\mathrm{H}_{1}=$ School belonging scale scores of the students differ significantly according to the absentee rate.

Table 6. Independent Samples t-test Results by Gender

\begin{tabular}{llrlllll}
\hline Absence & $\mathrm{N}$ & $\bar{X}$ & $S D$ & $\mathrm{df}$ & $t$ value & $p$ & $\eta^{2}$ \\
\hline Low & 106 & 84.58 & 18.44 & 210 & 3.43 & .001 & .053 \\
High & 106 & 75.88 & 18.46 & & & & \\
\hline
\end{tabular}

The scores of the students on the school belonging scale show a significant difference according to the absentee rate, $\mathrm{t}(210)=3.43, \mathrm{p}<.05$. Based on the findings, the students with a low absentee rate (84.58) were more positive than the students with the high absentee rate (75.88). The effect size calculated for the difference according to attendance is .053. The significant difference is close to the medium effect size.

\subsection{Reliability}

Reliability of the scores obtained from school belonging scale was calculated through Cronbach Alpha and Composite Reliability methods. The Cronbach's alpha reliability coefficients of the measures were found to be .91 for school engagement, .92 for teacher support, .72 for friend support and .71 for alienation to school, and .92 for the entire scale. Accordingly, the entire test can be said to be reliable in terms of internal consistency. Composite reliability coefficients of measurements were as follows; .92 for SE factor; .94 for TS factor; .83 for FS factor and .72 for AS factor. The overall reliability of the scale was .97. Since the reliability coefficient of .70 and above is accepted as reliable (Domino \& Domino, 2006), it can be said that the reliability coefficients of the scale are sufficient. The results for the reliability analysis are presented in Table 7.

Table 7. Reliability Coefficients for Belonging to School Scale and its Sub-factors

\begin{tabular}{lll}
\hline Scale & Cronbach Alpha & Composite Reliability \\
\hline School Engagement & .91 & .92 \\
Teacher Support & .92 & .94 \\
Friend Support & .72 & .83 \\
Alienation to School & .71 & .72 \\
Scale (total) & .93 & .97 \\
\hline
\end{tabular}

\subsection{Item Analysis}

Item analyzes were used for additional evidence of the validity and reliability of the scale. When the findings in Table 8 are examined. It is seen that the t-test values of the $27 \%$ lower and upper group scores of the school belonging scale items ranged between 3.09 and $12.86(p<.01)$. In addition, the results of item-total correlations were between .302 and .757 . Item-total 
correlation provides information about the level of the item discrimination. According to the literature, the items having .30 and above are considered as sufficient for discrimination. Therefore, it can be said that all items in the scale have a value above the cut-off point and therefore all of the items in the scale are distinctive items.

Table 8. Analysis of School Belonging Scale Items

\begin{tabular}{lllllll}
\hline $\begin{array}{l}\text { New Item } \\
\text { Number }\end{array}$ & Old Item & $\begin{array}{l}\text { Reliability if item } \\
\text { deleted }\end{array}$ & $\begin{array}{l}\text { Item-Total } \\
\text { Correlation }\end{array}$ & $\bar{X}$ & $S D$ & $t$ value \\
\hline SE1 & M1 & .927 & .718 & 3.61 & 1.21 & $12.30^{*}$ \\
SE2 & M6 & .927 & .683 & 3.23 & 1.30 & $12.01^{*}$ \\
SE3 & M7 & .929 & .580 & 2.79 & 1.34 & $9.16^{*}$ \\
SE4 & M8 & .928 & .632 & 3.57 & 1.20 & $8.79^{*}$ \\
SE5 & M11 & .928 & .628 & 3.46 & 1.37 & $8.57^{*}$ \\
SE6 & M12 & .926 & .710 & 3.35 & 1.46 & $11.51^{*}$ \\
SE7 & M21 & .926 & .712 & 2.96 & 1.50 & $12.61^{*}$ \\
SE8 & M24 & .929 & .575 & 2.56 & 1.48 & $8.93^{*}$ \\
SE9 & M26 & .926 & .757 & 3.51 & 1.26 & $12.86^{*}$ \\
SE10 & M28 & .927 & .660 & 3.17 & 1.40 & $10.06^{*}$ \\
TS1 & M17 & .927 & .657 & 3.55 & 1.40 & $11.13^{*}$ \\
TS2 & M31 & .927 & .664 & 3.65 & 1.35 & $10.72^{*}$ \\
TS3 & M33 & .926 & .713 & 3.58 & 1.35 & $11.32^{*}$ \\
TS4 & M34 & .928 & .625 & 3.18 & 1.28 & $9.65^{*}$ \\
TS5 & M35 & .926 & .721 & 3.53 & 1.41 & $12.52^{*}$ \\
TS6 & M37 & .926 & .716 & 3.75 & 1.33 & $11.20^{*}$ \\
FS1 & M4 & .932 & .401 & 4.66 & .563 & $4.24^{*}$ \\
FS2 & M25 & .931 & .424 & 3.91 & 1.16 & $5.42^{*}$ \\
FS3 & M29 & .929 & .552 & 4.13 & 1.13 & $8.13^{*}$ \\
FS4 & M32 & .932 & .404 & 3.75 & 1.24 & $5.64^{*}$ \\
AS1 & M10 & .932 & .376 & 4.10 & 1.13 & $4.61^{*}$ \\
AS2 & M19 & .935 & .302 & 3.95 & 1.22 & $3.09^{*}$ \\
AS3 & M20 & .932 & .333 & 4.26 & 1.09 & $3.50^{*}$ \\
\hline
\end{tabular}

*significant at the .01 level.

\subsection{Interpretation of School Belonging Scale Scores}

The school belonging scale consists of 23 items and has a 5-point Likert-type rating. As a result of exploratory factor analysis (EFA), the 23 -item scale having 4 sub-factors were obtained. In order to confirm the structure obtained in EFA, confirmatory factor analysis (CFA) was applied and satisfying goodness of fit indices were obtained. Therefore, the second-order CFA analysis were computed whether the scale had unidimensional. The analysis results attested that it was "unidimensional". This finding can be interpreted that the researchers and educators using this scale can make interpretations based on both sub-factors and total score of the scale. The score range can be between 23-115. The increase in the scores obtained from the school belonging scale can be interpreted as an indication of a higher level of school belonging.

\section{DISCUSSION and CONCLUSION}

In this study, it was aimed to develop a valid and reliable scale which can be used to measure school belonging level of the middle school students. When the different studies in the national and international literature were examined, it was found that the sense of school belonging had a significant impact on the affective, cognitive and social development characteristics of the students inside and outside the school. According to the studies in the literature, the students with a high sense of school belonging were academically more successful, more willing to study and learn, pro-social, had better teacher-student relationships, felt less lonely and anxious, participated in-and-out-of-class activities more, were more satisfied with their current situation 
and highly motivated (Cemalcilar, 2010; Finn, 1989; Goodenow \& Grady, 1993; Sar1, 2013; Voelkl, 1997). On the other hand, students with a low sense of belonging are characterized by negative attitudes towards the school, behavioural problems, low academic achievement, alienation, and high emotional and low attendance rates (Edwards \& Mullis, 2001; Voelkl, 1997). In line with these findings, a valid and reliable measurement tool is required to accurately measure school belonging level. Various measurement tools (Goodenow, 1993; Malone, Pillow \& Osman, 2012) are available in the international literature developed for this purpose. However, since they are in different languages, efficient and effective results cannot be obtained due to the linguistic competence factor when they are administered to students. In addition to this, some measurement tools either consider the concept of belonging as a general belonging (Malone, Pillow \& Osman, 2012) and do not concentrate on the phenomenon of school belonging (Keskin \& Pakdemirli, 2016) or are based on the data of the students studying in two different levels, middle school and high school (Aslan \& Duru, 2017). Therefore, the scale entitled with "School Belonging Scale" developed within the scope of this study is considered to be important in filling the gap in national and international literature as a tool which possesses valid and reliable psychometric properties in determining the school belonging level of the middle school students.

In this study, the research data were collected from 855 middle school students who were divided into three groups (Group $\mathrm{I}=287$, Group $\mathrm{II}=312$, Group $\mathrm{III}=256$ ). Missing values and outliers were eliminated from the total data and the analyses were performed with the rest (Group I=218, Group II=276, Group III=212). The data of the first group were used in the exploratory factor analysis. According to the EFA findings, 5 items were excluded from the scale since their factor loadings were below the pre-determined value of .50 and 9 items were overlapping, so they were removed. As a result, a 23-item scale consisting of four sub-factors were obtained from the 37-item initial version. Considering the items in the factors and the theoretical basis, the first factor was named as School Engagement (SE), the second factor was Teacher Support (TS), the third factor was Friend Support (FS) and the fourth factor was Alienation to School (AS). The first factor (SE) consisted of 10 items whose factor loadings ranged from .50 to .88 . The second one (TS) comprised of 6 items whose factor loadings were between .64 and .97 . The third one (FS) composed of 4 items having factor loadings between .68 and .78. The last one (AS) consisted of 3 items having factor loadings between .79 and .82. The total variance explained was $63.89 \%$ and it was the first factor to contribute it in the highest amount $(41.34 \%)$. The others' degree of contribution were as follows: $9.62 \%, 7.78 \%$ and $5.06 \%$.

The results of the EFA were tested with the second-order confirmatory factor analysis (CFA) to confirm whether the structure consisting of 23 items and 4 factors was essentially verified as a model measuring a dimension. The data of the second group were used to perform this analysis. As a result of the second-order CFA analysis, 11 goodness of fit indices (including $\chi^{2} / \mathrm{df}$ value) were examined. Since the fit indices obtained from the analysis were between absolute (IFI, NFI, NNFI and CFI) and acceptable ( $\chi^{2} / \mathrm{df}$, GFI, RMSEA, AGFI, SRMR, PNFI and PGFI) values, the model was confirmed. This finding was also observed in the path diagram of the model.

In addition to EFA and CFA, hypothesis testing was also performed. When the researches in the related literature were examined, it was noteworthy that the absentee rate at school was related to students' sense of belonging to the school (Cemalcilar, 2010; Edward \& Mullis, 2001; Voekl, 1997). It was expected that students with low absentee rate would have higher levels of belonging to students than students with high absentee rate. Accordingly, the data were divided into two groups as low and high absenteeism. As a result of the t-test performed to these groups, it was found that the students' school belonging scale scores showed a significant difference 
according to their attendance status. This finding showed that the evidence for absentee rate and sense of belonging to the literature was put forward by the developed scale and confirmed the hypothesis of this relationship.

In addition to the evidence of construct validity, Cronbach's alpha and composite reliability coefficients were calculated for the reliability of the school belonging scale. The Cronbach's alpha reliability coefficients of the measures were found to be .91 for school engagement, .92 for teacher support, 0.72 for friend support and 0.71 for alienation to school, and .92 for the entire scale. Accordingly, the entire scale can be said to be reliable in terms of internal consistency. Composite reliability coefficients of measurements were; .92 for SE factor; .94 for TS factor; .83 for FS factor and .72 for AS factor. The overall reliability of the scale was .97 . In the literature, the value of the reliability coefficient of .70 and above is accepted as an indication that the measurements are reliable (Domino \& Domino, 2006). When this information is considered, it can be said that both Cronbach Alpha and composite reliability coefficients of the scale are sufficient.

It was found that the item-total correlation values of the items were between .302 and .757. As stated before, these values provide information about the level of discrimination of the items in the scale. Considering that the items above .30 have sufficient value in terms of discrimination in the literature, it can be said that each of the items in the scale is discriminative.

The findings of the second-order CFA analysis showed that the 23 -item school belonging scale, which had a five-point Likert-type rating, was a unidimensional model although it had a four sub-factor structure. In this respect, a total score can be obtained from the scale and interpretations can be made on this score. The range of scores from the scale varies between 23 and 115. The increase in the scores obtained from the school belonging scale means that the students' level of belonging to the school is high (Appendix, Table A1).

In addition to the strengths listed above of the research, the research has some limitations. These limitations bring some suggestions for future research and researchers. First of all, the data collected within the scope of this research is limited to the students attending middle school (5, 6, 7 and $8^{\text {th }}$ grade). As Bademci (2013) states, reliability findings are considered to be characteristics related to measurements, whereas interpretations made as a result of measurements are accepted as validity characteristics. In this respect, it is necessary to renew the validity and reliability analyses for the data to be collected from different study groups. Another suggestion is for researchers who will conduct research using the school belonging scale. When the literature related to school belonging is examined, it is found that school belonging is related to variables such as academic achievement, number of attendance, studentteacher relationship, attitudes towards school, the participation rate in classroom-outside activities. It is thought that when the researchers collect data by taking these variables into consideration, they may easily make descriptive definitions of their study groups.

\section{Declaration of Conflicting Interests and Ethics}

The authors declare no conflict of interest. This research study complies with research publishing ethics. The scientific and legal responsibility for manuscripts published in IJATE belongs to the author(s).

\section{ORCID}

Bekir Direkci (iD https://orcid.org/0000-0002-6951-8567

Mehmet Canbulat (iD https://orcid.org/0000-0002-1781-2684

İbrahim Hakk1 Tezci (D) https://orcid.org/0000-0003-0273-8853

Serdar Akbulut (iD https://orcid.org/0000-0002-5809-1481 


\section{REFERENCES}

Adelabu, D.D. (2007). Time perspective and school membership as correlates to academic achievement among African American adolescents. Adolescence, 42(167), 525-538.

Akar-Vural, R., Yılmaz-Özelçi, S., Çengel, M., \& Gömleksiz, M. (2013). The development of the "Sense of Belonging to School" Scale. Eurasian Journal of Educational Research. $53,215-230$.

Alkan, N. (2015). Psychological sense of university membership: An adaptation study of the PSSM scale for Turkish university students. The Journal of Psychology, 150(4), 431-449.

Anderman, E.M. (2002). School effects on psychological outcomes during adolescence. Journal of Educational Psychology, 94(4), 795-809.

Awang, Z. (2015). SEM made simple: a gentle approach to learning Structural Equation Modelling. Bandar Baru Bangi: MPWS Rich Publication.

Aslan, G., \& Duru, E. (2017). Initial development and validation of the school belongingness scale. Child Indicators Research, 10, 1043-1058.

Bademci, V. (2013). Değerbiçiciler arası (interrater) ölçüm güvenirliğinin Cronbach'ın alfası ile kestirilmesi [Estimation of Interrater Score Reliability by the Cronbach's Alpha]. Journal of Industrial Arts Education Faculty, 30, 55-62.

Bentler, P.M. (1980). Multivariate analysis with latent variables: Causal modeling. Annual Review of Psychology, 31, 419-456.

Bond, L., Butler, H., Thomas, L., Carlin, J., Glover, S., Bowes, G., \& Patton, G. (2007). Social and school connectedness in early secondary school as predictor of late teenage substance use, mental health, and academic outcomes. Journal of Adolescent Health, 40 (4), 357 366.

Booker, K.C. (2006). School belonging and the African American adolescent: What do we know and where should we go? The High School Journal, 89(4), 1-7.

Byrne, B.M. (2010). Structural equation modeling with AMOS: Basic concepts, applications and programming. New York, NY: Taylor and Francis Group.

Byrne, B.M., \& Campbell, T.L. (1999). Cross-cultural comparisons and the presumption of equivalent measurement and theoretical structure: A look beneath the surface. Journal of Cross-Cultural Psychology, 30, 557-576.

Büyüköztürk, Ş. (2016). Sosyal bilimler için veri analizi el kitabı- istatistik, araştırma deseni, SPSS uygulamalart ve yorum (22. Bask1). Ankara: Pegem Akademi

Cattell, R.B. (1978) The scientific use of factor analysis in behavioral and life sciences. Plenum, New York.

Cemalcilar, Z. (2010). Schools as socialization contexts: Understanding school factors' impact on students' sense of school belonging. Applied Psychology: An International Review, 59(2), 243-272.

Comrey, A.L., \& Lee, H.B. (1992). A first course in factor analysis (2nd ed.). Hillsdale, NJ: Lawrence Erlbaum.

Costello, A.B., \& Osborne, J.W. (2005). Best practices in exploratory factor analysis: Four recommendations for getting the most from your analysis. Practical Assessment Research \& Evaluation, 10(7), 1-9.

Çokluk, Ö., Şekercioğlu, G., \& Büyüköztürk, Ş. (2012). Sosyal bilimler için çok değişkenli istatistik: SPSS ve LISREL uygulamalart [Multivariate Statistics for Social Sciences: SPSS and LISREL Applications]. Ankara: Pegem Academy Publishing.

Domino, G., \& Domino, M.L. (2006). Psychological testing: An introduction. Cambridge: Cambridge University Press.

Duru, E. (2015). Genel aidiyet ölçeğinin psikometrik özellikleri: Geçerlik ve güvenirlik çalışması. Türk Psikolojik Danışma ve Rehberlik Dergisi, 5(44), 37-47. 
Edwards, D., \& Mullis, F. (2001). Creating a sense of belonging to build safe schools. Journal of Individual Psychology, 57(2), 196-203.

Fabrigar, L.R., Wegener, D.T., MacCallum, R.C., \& Strahan, E.J. (1999). Evaluating the use of exploratory factor analysis in psychological research. Psychological Methods, 4(3), 272299.

Ferguson, E., \& Cox, T. (1993). Exploratory factor analysis: A users' guide. International Journal of Selection and Assessment, 1(2), 84-94.

Finn, J. (1989). Withdrawing from school. Review of Educational Research, 59, 117-142.

Goodenow, C. (1992). Strengthening the links between educational psychology and the study of social contexts. Educational Psychologist, 27, 177-196.

Goodenow, C. (1993). The psychological sense of school membership among adolescents: Scale development and educational correlates. Psychology in the Schools, 30, 79-90.

Goodenow, C., \& Grady, K. (1993). The relationship of school belonging and friends' values to academic motivation among urban adolescent students, The Journal of Experimental Education, 62, 60-71.

Hagborg, W.J. (1994). An exploration of school membership among middle and high school students. Journal of Psychological Assessment, 12, 312-323.

Hagerty, B.M., Williams, R.A., Coyne, J.C., \& Early, M.R. (1996). Sense of belonging and indicators of social and psychological functioning. Archives of Psychiatric Nursing, 10(4), 235-244. http://dx.doi.org/10.1016/S0883-9417(96)80029-X

Hair, J.F., Anderson, R.E., Tatham, R.L., \& Grablowsky, B.J. (1979). Multivariate data analysis. Tulsa, OK: Pipe Books.

Hu, L.-t., \& Bentler, P.M. (1999). Cutoff criteria for fit indexes in covariance structure analysis: Conventional criteria versus new alternatives. Structural Equation Modeling, 6(1), 1-55.

Ireson, J., \& Hallam, S. (2005). Pupils' liking for school: Ability grouping, self-concept, and perceptions of teaching. British Journal of Educational Psychology,75(2), 297-311.

Isakson, K., \& Jarvis, P. (1999). The adjustment of adolescents during the transition into high school: A short term longitudinal study. Journal of Youth and Adolescence, 28(1), 1-26.

Israelashvili, M. (1997). School adjustment, school membership, and adolescents' future expectations. Journal of Adolescence, 20, 525-535.

İlhan, M., \& Çetin, B. (2014) Sınıf değerlendirme atmosferi ölçeğinin (SDAÖ) geliştirilmesi: geçerlilik ve güvenirlik çalışması [Development of Classroom Assessment Environment Scale (CAES): Validity and Reliability Study]. Education and Science, 39(176),31-50.

Jöreskog, K., \& Sörbom, D. (2000). LISREL [Computer Software]. Lincolnwood, IL: Scientific Software, Inc.

Kalaycı, Ş. (2010). Faktör analizi [Factor Analysis]. Ş. Kalaycı, (Ed.), SPSS uygulamalı çok değişkenli istatistik teknikleri [Multivariate Statistical Techniques with SPPS Applications]. Ankara: Asil Publishing. Assessment, 1(2), 84-94.

Keskin, R., \& Pakdemirli, M.N. (2016). Mesleki aidiyet ölçeği: Bir ölçek geliştirme, geçerlilik ve güvenirlik çalışması. Uluslararası Sosyal Araştırmalar Dergisi, 9(43), 2580-2587.

Kline, R.B. (1994). An easy guide to factor analysis. New York: Routledge.

Kline, R.B. (2011). Principles and practice of structural equation modeling. New York: The Guilford Press.

Malone, G.P., Pillow, D.R., \& Osman, A. (2012). The General belongingness scale (GBS): Assessing achieved belongingness. Personality and Individual Differences, 52, 311-316.

Marsh, H.W., Hau, K.T., Artelt, C., Baumert, J., \& Peschar, J.L. (2006). OECD’s brief selfreport measure of educational psychology's most useful affective constructs: Crosscultural, psychometric comparisons across 25 countries. International Journal of Testing, 6(4), 311-360. 
McMahon, S.D., Parnes, A.L., Keys, C.B., \& Viola, J.J. (2008). School belonging among lowincome urban youth with disabilities: Testing a theoretical model. Psychology in the Schools, 45(5), 387-401.

Meydan, C.H., \& Şeşen, H. (2011). Yapısal Eşitlik Modellemesi - AMOS Uygulamaları, Ankara: Detay Yayıncilık.

Osborne, J.W., \& Walker, C. (2006). Stereotype threat, identification with academics, and withdrawal from school: Why the most successful students of color might be most likely to withdraw. Educational Psychology, 26(4), 563-577.

Osterman, F. K. (2000). Students' need for belonging in the school community. Review of Educational Research, 70(3), 323-367.

Pehlivan, Z. (2006). Resmi genel liselerde ögrenci devamsızlı̆̆l ve buna dönük okul yönetimi politikalarl (Ankara ili örneği) [The Absenteeism at State Secondary Schools and Related School management Policies-ANKARA Case]. Unpublished Dissertation. Ankara: Ankara University Graduate School of Educational Sciences.

Pretty, G. M., Andrewes, L., \& Collett, C. (1994). Exploring adolescents' sense of community and its relationship to loneliness. Journal of Community Psychology, 22(4), 346-358

Roeser, R.W., Midgley, C., \& Urdan, T. (1996). Perceptions of the psychological environment and early adolescents' psychological and behavioral functioning in school: The mediating role of goals and belonging. Journal of Educational Psychology, 88, 408-422.

Sarı, M. (2013). Lise Öğrencilerinde Okula Aidiyet Duygusu [Sense of School Belonging Among High School Students]. Anadolu University Journal of Social Sciences, 10(1), 147-160.

Schermelleh-Engel, K., Moosbrugger, H., \& Müller, H. (2003). Evaluating the fit of structural equation models: Test of significance and descriptive goodness-of-fit measures. Methods of Psychological Research-Online, 8(2), 23-74.

Stevens, J. (1996). Applied multivariate statistics for the social sciences. Mahwah, NJ: Lawrence Erlbaum Associates.

Şencan, H. (2005). Sosyal ve davranışsal ölçümlerde güvenirlik ve geçerlilik [Reliability and Validity in Social and Behavioral Measurements]. Ankara: Seçkin Publishing.

Tabachnick, B. G., \& Fidell, L. S. (2007). Using multivariate statistics. Boston, Pearson Education, Inc.

Thompson, B. (2004). Exploratory and confirmatory factor analysis: Understanding concepts and applications. Washington DC: American Psychological Association

Van Ryzin, M. J., Gravely, A. A., \& Roseth, C. J. (2009). Autonomy, belongingness, and engagement in school as contributors to adolescent psychological well-being. Journal of Youth and Adolescence, 38(1), 1-12. http://dx.doi.org/10.1007/s10964-007-9257-4

Voelkl, K.E. (1997). Identification with school. American Journal of Education, 105, 294-317.

Willms, J. (2003). Student engagement at school: A sense of Belonging and Participation, Results from PISA 2000, OECD. 


\section{APPENDIX}

Table A1. School Belonging Scale for Middle School Students

\begin{tabular}{|c|c|c|}
\hline $\begin{array}{l}\text { Previous } \\
\text { Item } \\
\text { Number }\end{array}$ & Turkish Version & English Version (Suggested) ${ }^{*}$ \\
\hline 1 & Okulumu Severim. & I like my school. \\
\hline 6 & Okulda kendimi huzurlu hissederim. & I feel peaceful at school. \\
\hline 7 & Okula gelmek için can atarım. & I long to come to school. \\
\hline 8 & Okulda kendimi güvende hissederim. & I feel safe at school. \\
\hline 11 & $\begin{array}{l}\text { Kendimi bu okulun bir parçası olarak } \\
\text { görürüm. }\end{array}$ & I see myself as a part of this school. \\
\hline 12 & $\begin{array}{l}\text { Bu okulun bir öğrencisi olduğum için } \\
\text { kendimi şanslı hissederim. }\end{array}$ & I feel lucky to be a student of this school. \\
\hline 21 & Okul benim ikinci evimdir. & The school is my second home. \\
\hline 24 & $\begin{array}{l}\text { Okulda daha fazla zaman geçirmek } \\
\text { isterim. }\end{array}$ & I would like to spend more time at school. \\
\hline 26 & Okulda kendimi mutlu hissederim. & I feel happy at school. \\
\hline 28 & Okula kendimi ait hissederim. & I feel like I belong to school. \\
\hline 17 & Öğretmenlerim duygularıma önem verir. & My teachers care about my feelings. \\
\hline 31 & $\begin{array}{l}\text { Öğretmenlerim düşüncelerimi söylemem } \\
\text { konusunda beni destekler. }\end{array}$ & $\begin{array}{l}\text { My teachers support me in expressing my } \\
\text { thoughts. }\end{array}$ \\
\hline 33 & Öğretmenlerim düşüncelerimi dinler. & My teachers listen to my thoughts. \\
\hline 34 & $\begin{array}{l}\text { Okulda öğretmenlerim beni her etkinliğe } \\
\text { dâhil eder. }\end{array}$ & $\begin{array}{l}\text { My teachers involve me in every activity } \\
\text { at school. }\end{array}$ \\
\hline 35 & $\begin{array}{l}\text { Okuldaki öğretmenler fikirlerimize saygı } \\
\text { gösterir. }\end{array}$ & The teachers at school respect our ideas. \\
\hline 37 & $\begin{array}{l}\text { Okuldaki öğretmenler bize hoşgörülü } \\
\text { davranır. }\end{array}$ & $\begin{array}{l}\text { The teachers at school treat us with } \\
\text { tolerance. }\end{array}$ \\
\hline 4 & $\begin{array}{l}\text { Okulda arkadaşlarımla zaman } \\
\text { geçirmekten hoşlanırım. }\end{array}$ & $\begin{array}{l}\text { I like spending time with my friends at } \\
\text { school. }\end{array}$ \\
\hline 25 & $\begin{array}{l}\text { Okulda arkadaşlarım arasında kendimi } \\
\text { değerli hissederim. }\end{array}$ & $\begin{array}{l}\text { I feel valuable among my friends at } \\
\text { school. }\end{array}$ \\
\hline 29 & $\begin{array}{l}\text { Okulda arkadaşlarımla etkinlik yapmaktan } \\
\text { mutlu olurum. }\end{array}$ & $\begin{array}{l}\text { I feel happy to do activities with my } \\
\text { friends at school. }\end{array}$ \\
\hline 32 & $\begin{array}{l}\text { Planlarıma okul arkadaşlarımı dâhil } \\
\text { ederim. }\end{array}$ & I involve my friends in my plans. \\
\hline 10 & Okulda kendimi dışlanmış hissederim. & I feel left out at school. \\
\hline 19 & $\begin{array}{l}\text { Okuldaki diğer öğrencilerle birlikteyken } \\
\text { kendimi yabancı gibi hissederim. }\end{array}$ & $\begin{array}{l}\text { I feel like a stranger when I am with other } \\
\text { students at school. }\end{array}$ \\
\hline 20 & Okulda kendimi yalnız hissederim. & I feel lonely at school. \\
\hline
\end{tabular}

\footnotetext{
* The scale was translated into English by two experts in the Department of English Language Teaching. It was then translated back into the original language (Turkish) by different experts. Therefore, the researchers planning to use English version are required to conduct factor analysis and recheck reliability of the scale.
} 